\title{
Power Analysis and Geopolitical Codes of South China Sea States in the Context of Contemporary Geopolitics
}

\begin{abstract}
The analysis in this article provides an overview of the research on the current relations among countries of the South China Sea basin. For this purpose, I have decided to apply the geopolitical research workshop, focusing on its contemporary approach. On the one hand, this work uses the available indicators and index to gauge the level of development, economic and demographic potential, and military expenditure of these states. On the other hand, an effort was made to analyze and measure power, taking into account the changing geopolitical status of countries in this sub-region.

Contemporary geopolitics in this context allows to verify the scale of the impact on permanent environmental and geographic factors (e.g. publicized investments carried out by the People's Republic of China in Mischief Reef, Fiery Cross, Subi Reef and Woody Island) and the elaboration of proposals going beyond the classical, geopolitical framework (morphological, political and military factors). Therefore, this article also includes the use of geopolitical codes to assess the current strategies of these countries and to describe potential scenarios of actors' behaviour in the sub-region.
\end{abstract}

Keywords: geopolitics, critical and contemporary geopolitics, South China Sea, geopolitical codes, power, power measurement

The analysis in this article provides an overview of the research on the current relations among countries of the South China Sea basin. For this purpose, I have decided to apply the geopolitical research workshop, focusing on its contemporary approach. On the one hand, this work uses the available indicators and index to gauge the level of development, economic and demographic potential, and military expenditure of these states by exploring the significance of social and human actions and non-permanent geopolitical factors like the economy, demography, military potential, etc. On the other hand, an effort was made to analyze and measure power, taking into account the changing geopolitical status of countries in this sub-region by applying the geopolitical codes of the indicated states. 
Contemporary geopolitics in this context allows to verify the scale of the impact on permanent environmental and geographic factors (e.g. publicized investments carried out by the People's Republic of China in Mischief Reef, Fiery Cross, Subi Reef and Woody Island) and the elaboration of proposals going beyond the classical geopolitical framework. The index is not only based on morphological, territorial, political, cultural and military factors because elements of the introduced index structure have a more social and humandependent character. Therefore, this article also includes the use of geopolitical codes to assess the current strategies of these countries, and to describe potential scenarios of actors' behaviour in this sub-region by showing correlations between the proposed power index and geopolitical codes and their influence on potential decision-making processes.

\section{Power Measurement, Geopolitical Codes and Their Application - Literature Review in Poland and Internationally}

The measurement of power and the use of geopolitical codes have already served as a methodological approach in several works in Poland and around the world. In this context, the achievements and publications of Leszek Moczulski and Mirosław Sułek deserve special attention (Leszek Moczulski - Geopolityka - potęga w czasie i przestrzeni (1999), Mirosław Sułek - Potegga państw. Modele i zastosowania (2013), Robert Białoskórski, Robert Kobryński, Mirosław Sułek, Potęga państw 2017. Międzynarodowy układ sił w procesie zmian. Raport potęgometryczny (2017) and Robert Białoskórski, Łukasz Kiczma, Mirosław Sułek, Potęga państw 2018. Międzynarodowy układ sił w procesie zmian. Raport potegometryczny (2018). These authors measured the power of states in the international arena. It is also worth emphasizing the overall contribution of Mirosław Sułek to the development of research on power in Poland in the field of powernomy and powermetrics. This last point will be broadly discussed in detail later on. Geopolitical codes have been a subject of study in a work by Przemysław Osiewicz entitled: Geopolitical codes of the United States and the European Union: convergent and divergent aspects (2016).

With reference to international literature, it is worth mentioning the following authors, who used research instruments of power measuring and geopolitical codes:

- F. Clifford German - A tentative evaluation of world power (1960),

- Ray S. Cline - World power assessment: a calculus of strategic drift (1977),

- Leslie W. Hepple - The revival of geopolitics (1986),

- Gertjan Dijkink - National identity and geopolitical visions: maps of pride and pain (1996),

- John O'Loughlin - Geopolitical visions of Central Europe (1997),

- Gertjan Dijkink - Geopolitical codes and popular representations (1998),

- Chin-Lung Chang - A measure of national power (2004),

- Paul C. Adams - The September 11 attacks as viewed from Quebec: the smallnation code in geopolitical discourse (2004), 
- Gregory F. Treverton, Seth G. Jones - Measuring national power (2005),

- Asteris Huliaras, Charalambos Tsardanidis - (Mis)understanding the Balkans: Greek geopolitical codes of the post-communist era (2006),

- Norman Gregor David Rae - Reinventing geopolitical codes in the post-Cold War world with special reference to international terrorism (2007),

- Seyed Hadi Zarghani - Measurement of national power: definitions, functions, measurement (2010),

- Karl Hermann Höhn - Geopolitics and the measurement of national power (2011),

- Saeid Naji, Jayum A. Jawan - US hegemonic leadership and its geopolitical codes (2011),

- Jongwoo Nam - The geographical construction of national identity and state interests by a weak nation-state: the dynamic geopolitical codes and stable geopolitical visions of North Korea, 1948-2010 (2012),

- Igor Okunev - A new dimension of Russia's geopolitical code (2013),

- Emre Ersen - Geopolitical codes in Davutoğlu's views toward the Middle East (2014),

- Mirja Schröder - The discursive construction of Turkey's role for European energy security: a critical geopolitical perspective (2017).

No author so far has applied the power measurement approach in combination with geopolitical tools to explore the South China Sea, and this is one of the underlying reasons for undertaking this analysis.

\section{Contemporary Geopolitics - Introduction and Basics}

Geopolitics as a field of study was introduced in the XIXth Century and had a significant impact on leaders of states and ruling elites until the end of World War II. The main representatives of classical geopolitics include, among others:

- Alfred Mahan: The influence of sea power upon history 1660-1783 (1890),

- Friedrich Ratzel: Political geography (1897),

- Rudolf Kjellen: The state as a living form (1916),

- Halford Mackinder: The geographical pivot of history: the natural seats of power, democratic ideals and reality (1919),

- Karl Haushofer: Geopolitik des Pazifischen Ozeans: Studien über die Wechselbeziehungen zwischen Geographie und Geschichte (1924).

The term geopolitics was strongly undermined as a result of its use in Nazi Germany under the guidance of the German geopolitician Karl Haushofer. In spite of the strong criticism after the Second World War, geopolitics continued to influence leaders and political decision-makers through to the Cold War. Its revival in the context of unequivocal reference to its foundations took place only in the 1970s. It was then that Colin S. Gray published 
his first work directly relating to geopolitics: Geopolitics of the nuclear era: heartland, rimlands, and the technological revolution (1977). At that time, modern geopolitics was also weaved in the current of contemporary geopolitics. Representatives include Gearoid O'Tuathail, Simon Dalby, John Angew, Klaus Dodds and Peter Taylor. The founder of an alternative variant of geopolitics was Yves Lacoste, a French geographer and geopolitician. He launched the French geopolitical journal Hérodote in 1976. Yves Lacoste has played a key role in the revival of the term geopolitics in French and English. In the late 1980s, Gearoid O'Tuathail coined the concept of 'critical geopolitics' in his work: Critical geopolitics: the social construction of state and place in the practice of statecraft (1989). Other works that had an impact on the development of critical geopolitics include:

- S. Dalby: Creating the Second Cold War, the discourse of politics (1990),

- J. Agnew: Mastering space: hegemony, territory and international political economy (1995),

- G.J. Dijkink: National identity and geopolitical visions, maps of pride and pain (1996).

The differences between classical geopolitics and contemporary and critical geopolitics revolve around ontological-epistemological issues, i.e. they refer to the surrounding reality on an objective or inter-subjective, subordinate or critical and textual level. These differences are best summarized by Leszek Sykulski as follows:

\begin{tabular}{|c|c|}
\hline Classical geopolitics $-19^{\text {th }}-20^{\text {th }} \mathrm{C}$. & Contemporary geopolitics $-20^{\text {th }}-21^{\text {st }} \mathrm{C}$. \\
\hline Industrial civilization & Information civilization \\
\hline Territorialization of politics & Deterritorialization of politics \\
\hline Nationalisms, nationalization of politics & Supranationalisms; denationalization of politics \\
\hline $\begin{array}{l}\text { Policy is played out within states, and political and } \\
\text { military blocs }\end{array}$ & $\begin{array}{l}\text { Global policy as a network: as important as the } \\
\text { state - non-state actors, international corporations } \\
\text { and non-state links }\end{array}$ \\
\hline Nationalization of capital & Globalization of capital \\
\hline $\begin{array}{l}\text { Key: material base, natural resources and infrastruc- } \\
\text { ture industries }\end{array}$ & Key: information and information infrastructure \\
\hline Horizon: (between-) continental & Horizon: astropolitical \\
\hline Dominance of politico-military factors & $\begin{array}{l}\text { Dominance of diplomatic factors, economic and } \\
\text { cultural }\end{array}$ \\
\hline Symmetrical threats & Asymmetric threats \\
\hline Fight for material resources & Fight for consciousness \\
\hline Domination of „perceived space” & Domination of „perceived and imaginary space” \\
\hline Cartography & Geographic Information systems (GIS) \\
\hline
\end{tabular}

Source: Sykulski, 2014, p. 15.

The development of critical geopolitics was influenced by humanistic geography, critical theory, post-structuralism and postmodernism. According to Jakub Potulski, the interest in 
critical geopolitics arose in the community of geography and international relations scholars. They turned to the study of geopolitics in the 1980 s as a social, cultural and political practice rather than as a reflection of real politics (Potulski, 2010, p. 260; O'Tuathail, Dalby, 1998, p. 2), and they drew on postmodernist, critical theory and post-structuralist ideas (Jacques Derrida and Michael Foucault). Potulski also claims that in terms of critical geopolitics, 'the geography is not an unchanging foundation of human action, as some would like to see it, but a historical and social form of knowledge about the earth'(Potulski, 2010, p. 262). In this regard, human impact on the natural and geographic environment, and more specifically for this article, Chinese projects on artificial islands in the South China Sea (see photos below), climate change caused by the excessive expansion and development of industry, and critical analysis of geopolitical factors and their impact on the South China Sea in isolation from real politics or diplomacy are the main concerns of contemporary geopolitics. Such an approach allows for a thorough observation of the political practice of states in this region, as well as their identity and values, which have not yet led to open armed conflict.

\section{The South China Sea - Background and Origin of the Problem}

The South China Sea covers a total of 350,000 square $\mathrm{km}$. The problem lies with the multitude of contested geopolitical and territorial interests and claims in islands and other land-based forms in the Paracel (Xisha), Spratly (Nansha) and Pratas (Dongsha Qundao) regions, Macclesfield Bank and Scarborough Shoal (Huangyan Dao). The Paracel Islands are occupied by China. Vietnam and Taiwan also make claims against them. This archipelago covers approximately 130 islands. The subject of dispute in Spratly concerns about 175 islets. ${ }^{1}$ China, Vietnam, Taiwan, the Philippines, Malaysia and Brunei compete for them. Paracel and Spratly are administered by the Chinese province of Hainan.

The dispute over the small archipelago of Pratas (now under the administration of Taiwan) has inflamed tensions among Taiwan, China, Vietnam, the Philippines, Malaysia and Indonesia. China, Taiwan, the Philippines and Vietnam stake claims on Macclesfield Bank, while China, Taiwan and the Philippines on Scarborough Shoal. In addition, Malaysia, Cambodia, Thailand and Vietnam have territorial claims on selected parts of the Gulf of Thailand, and Singapore and Malaysia to Johor and the Singapore Strait.

The Chinese government refers to these disputed areas as the Southern Sea, Vietnam as the Eastern Sea, and Malaysia, Indonesia and the Philippines as the South China Sea. Further, the government of the Philippines has been using the term East Philippine Sea since 2011 on local maps. Finally, Indonesia introduced the name North-Natun Sea in 2017.

The origin of the dispute goes back to the 1930s, when for the first time Chinese pretensions to the islands had appeared on the world map. This coincided with the annexation

1 The largest island of this archipelago is Itu Aba, or Taiping under the current administration of Taiwan. 
of part of the archipelago of Paracel by France. By the end of World War II, China made demands to the areas occupied by Japan (Manchuria, Formosa and the Pescadores).

According to many analysts, Chinese territorial claims and their historical foundations go even further, to the period of the Han dynasty (206 BC - $220 \mathrm{CE}$ ). Over the subsequent centuries, the South China Sea together with the East China Sea and the Yellow Sea have become part of the so-called "Three seas", formulated during the Ming dynasty (1368-1644) in China (Hastedt, Lybecker, Shannon, 2015, p. 23).

The leader of the Republic of China in Taiwan, Chiang Kai-shek, issued a series of claims to this region under the so-called 11-Dash Line in 1947. This aspiration was then adopted by the People's Republic of China in the late 1940s and 1950s, and disseminated by the Chinese foreign minister Zhou Enlai what became known as 'the Nine-Dash Line' or 'cow's tongue' (this is how China's claims are perceived in Vietnam). China at that time marked its presence in the region of the archipelago of Paracel. South Vietnam inherited its claims from France in the 1950s. Finally, the Philippines promoted its demands in the Spratly area in 1956.

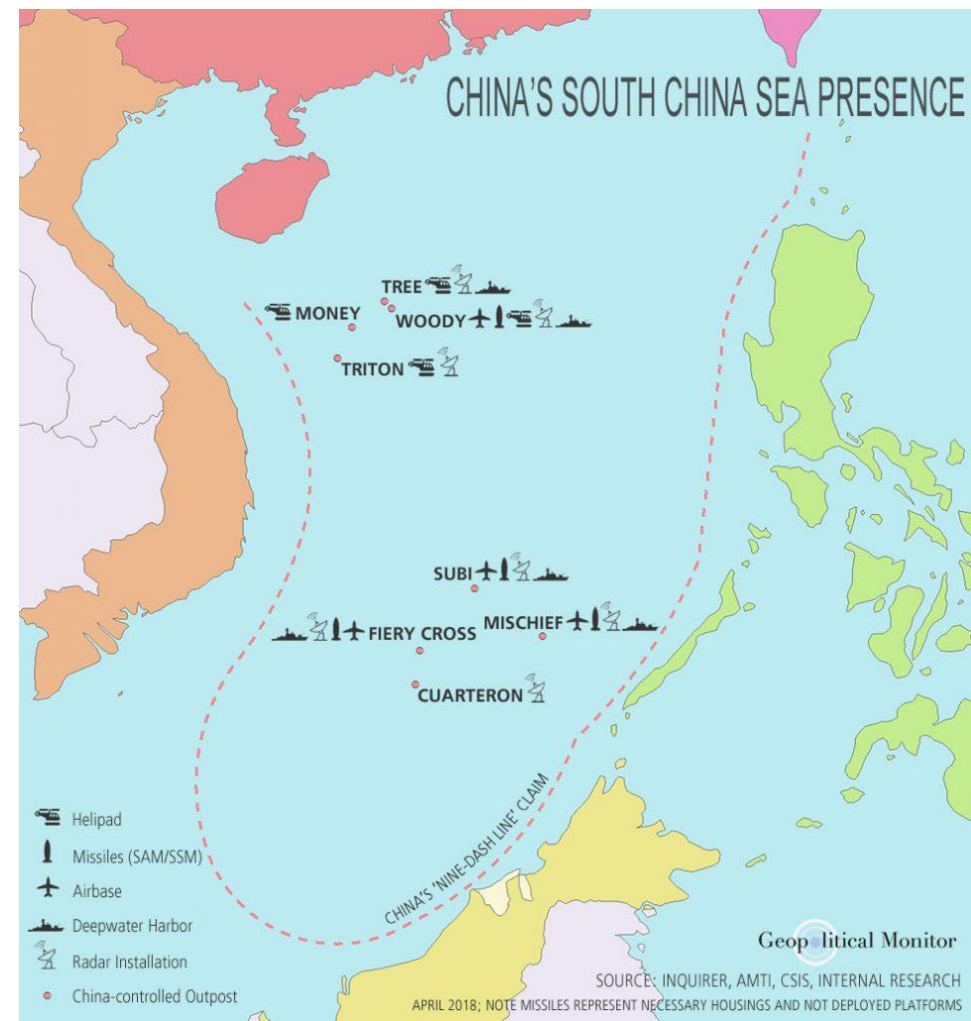

Map 1. China's presence in the South China Sea - the Nine-Dash Line

Source: South China Sea Dispute: China, Geopolitical Monitor, https://www.geopoliticalmonitor.com/south-china-sea-dispute-china/, 08.05.2018, [access: 23.05.18]. 
The significance of the region increased in the 1970s when oil and natural gas resources were discovered (so far countries have nominally acknowledged the supremacy of China). China took control of islands in the archipelago of Paracel in 1974, after a short conflict with South Vietnam. The Philippines announced their supremacy in Spratly after the discovery of oil resources in the Palawan Island in 1978. China has vied for control over unoccupied islands since the 1980s. The justification for Chinese claims in this regard is based on historical and material rights, i.e. dynastic conditions, the discovery of islands by Chinese sailors, traditional maritime borders, the instrumental approach to the continental shelf and the exclusive economic zone. 'At the end of the 1990s, the armed forces of Vietnam in the region had deployed around 600 soldiers on 25 land formations' (Potulski, 2010, p. 29).

Other countries, including China, challenge the compliance of different claims with international law and the United Nations Convention on the Law of the Sea (UNCLOS). 'In 2002, ASEAN and PRC signed a declaration on the conduct of the coastal states of the

\section{Territorial Claims in the South China Sea}

Six countries lay claim to at least a portion of the resource-rich Spratly Islands. The overlapping maritime claims combined with China's maritime expansionism and the involvement of major naval powers have roiled the waters in the South China Sea for most of the past six years.

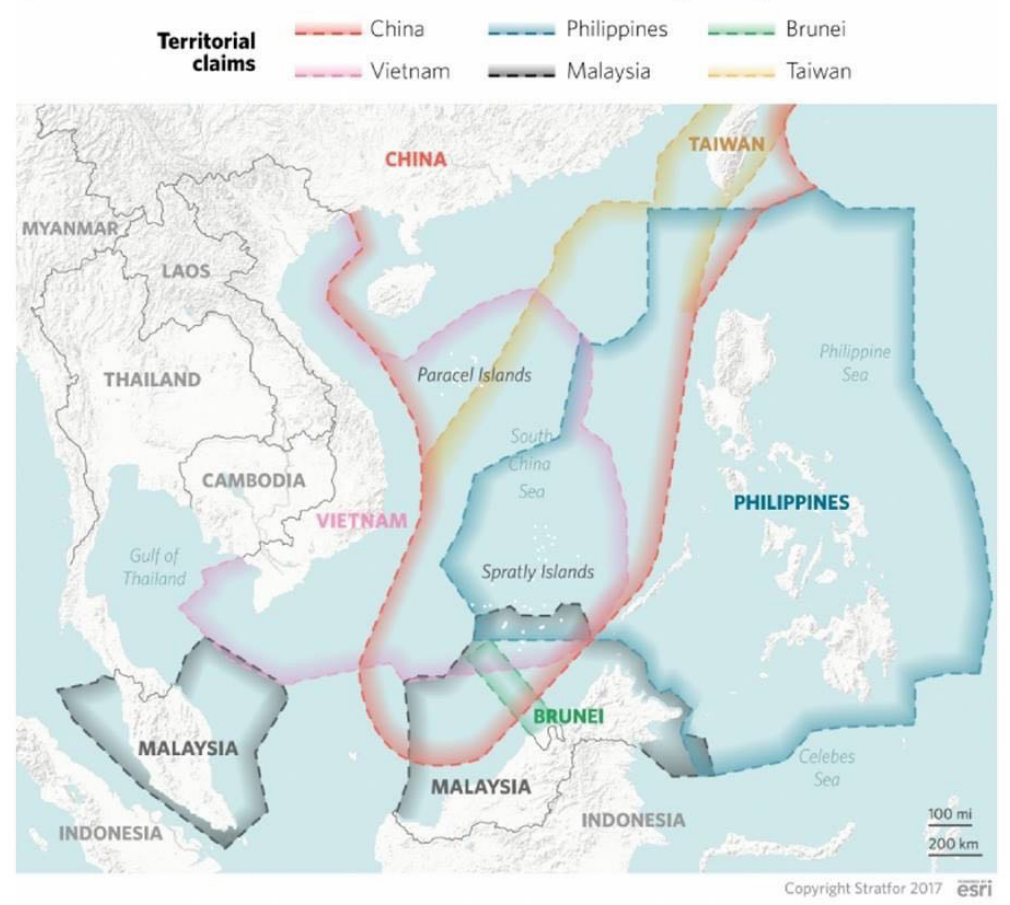

Map 2. The South China Sea - the main territorial claims

Source: Great Power Politics in the South China Sea, Stratfor 2017, https://worldview. stratfor.com/article/great-power-politics-south-china-sea, 26.10.2015, [access: 23.05.18]. 
region (the so-called Code of Conduct), which emphasized their will to resolve the conflict in accordance with international law. The situation changed in 2009 when Vietnam and Malaysia provided the UN Committee on Frontier Limits with information on the limits of their shelf' (Tarnogórski, 2016).

China increased the reach of its claims under the Nine-Dash Line in 2014. Currently, the Chinese authorities periodically introduce a moratorium on fishing in the South China Sea and the East China Sea and carry out regular military exercises and manoeuvres using their fleet to test new technologies in the area. In addition, they exert psychological and political pressure on other countries of the South China Sea and openly criticize all forms of activity of other actors (politico-military or economic). Their targets include the US, the UK, Australia, Japan, Russia and Spain. Additionally, for several years, Beijing has implemented a strategy of militarization of existing landforms, primarily in the archipelagos of Paracel and Spratly. In spite of the ongoing changes in the bilateral relations between China and some countries in the region (Brunei, Philippines), there is still a high level of interstate tension in the region.

\section{The Geopolitical Significance of the South China Sea}

Although the South China Sea, located in the western part of the Pacific Ocean in Southeast Asia, covers only mostly uninhabited islands, coral reefs, atolls, rocks or other land forms above and below the water level, it is one of the most contested territories in the world. The geopolitical meaning of the South China Sea can be understood if one takes into account the following aspects:

- It is an important transport and commercial corridor, as well as having strategic value for the Chinese Belt and Road Initiative architecture - over 5 billion dollars of goods and raw materials flow through these shipping lanes annually (Kelly, Kubo, 2017), 50\% of tankers use this sea route to transport oil.

- Strategic maritime routes in the area can be easily blocked as a result of an open armed conflict, including the Malacca Strait linking the South China Sea with the Indian Ocean, the Singapore Strait - linking the South China Sea and the Malacca Strait with the Andaman Sea and the Indian Ocean - the Taiwan Strait linking the South China Sea with the East China Sea, and the Balabac Strait - the exit to the Pacific Ocean and the Luzon Strait, which connects the Philippine Sea with the Pacific Ocean.

- It provides access to main ports: Hong Kong, Bangkok, Singapore, Guangzhou, Ho Chi Minh, Zhanjiang, Manila.

- It contains raw materials and their potential exploitation (crude oil - resources estimated at over 28 billion barrels (Daiss, 2018), natural gas - over 7,500 km3 (266 trillion cubic feet), fish $-10 \%$ of world resources, including stocks of tuna, herring 
and sardines). 'The value of the biological wealth of the Beijing region is estimated at around 1 trillion dollars' (Centre of International Relations, 2016). The Chinese government keeps introducing periodic moratoria for commercial fishing.

- In terms of continental shelf, it represents more than half of the floor area and the extent of the exclusive economic zone.

- It provides potential for the militarisation of areas through the creation of artificial islands and elements of military infrastructure (Friedman, Snyder and Ligon, 2017), in particular airports and hangars, military garrisons, radars, military installations (surface-to-air missiles on the Woody island or the Paracels), heliports, ports, public buildings, and even nuclear power plants among others.

- It affords proximity to strategic ports of the Chinese Navy and units stationed there with nuclear weaponry (Hainan Island).

- There are competing nationalist claims inherent in the policies of many countries in the region, including China, the Philippines, Vietnam, Taiwan and Thailand, which cause the dispute over the South China Sea to become a matter of prestige.

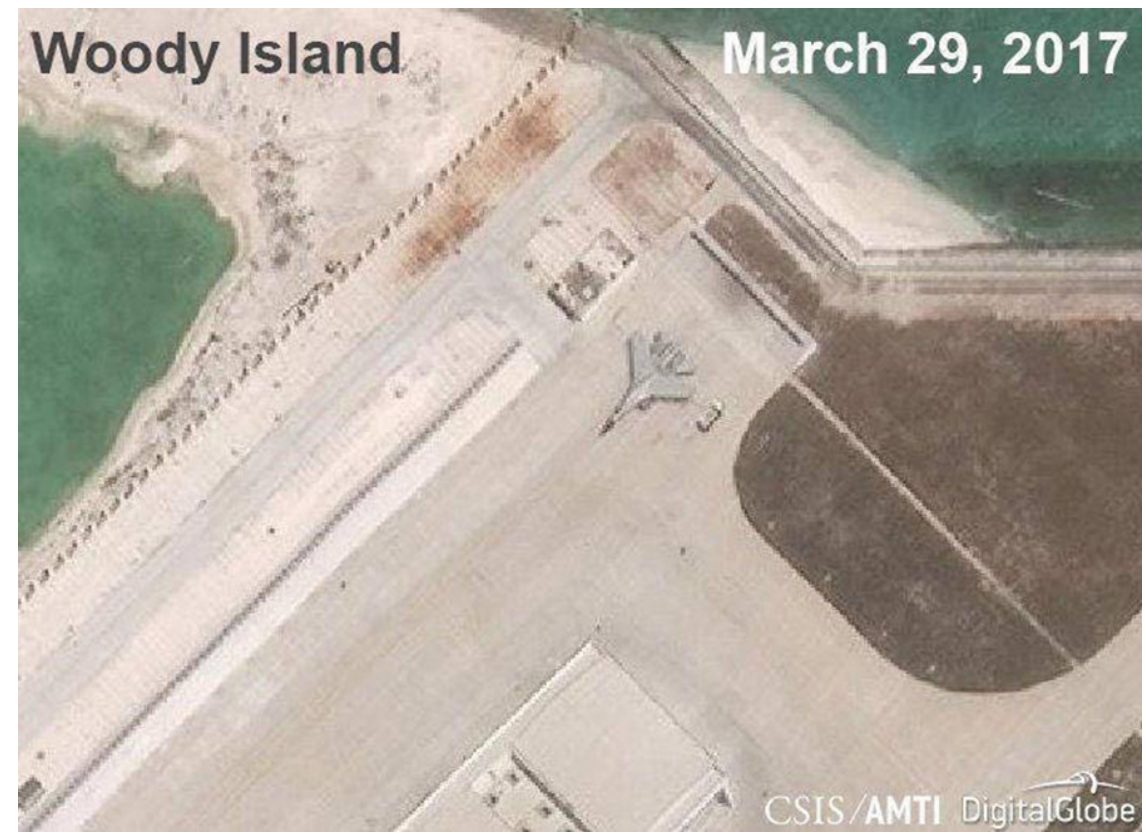

Picture 1. Military infrastructure and installations on Woody island in the Paracels

Source: China's Continuing Reclamation in the Paracels, Asia Maritime Transparency Initiative, Center for Strategic \& International Studies, https://amti.csis.org/paracels-beijings-other-buildup/, 09.08.2017, [access: 03.06.2018]. 


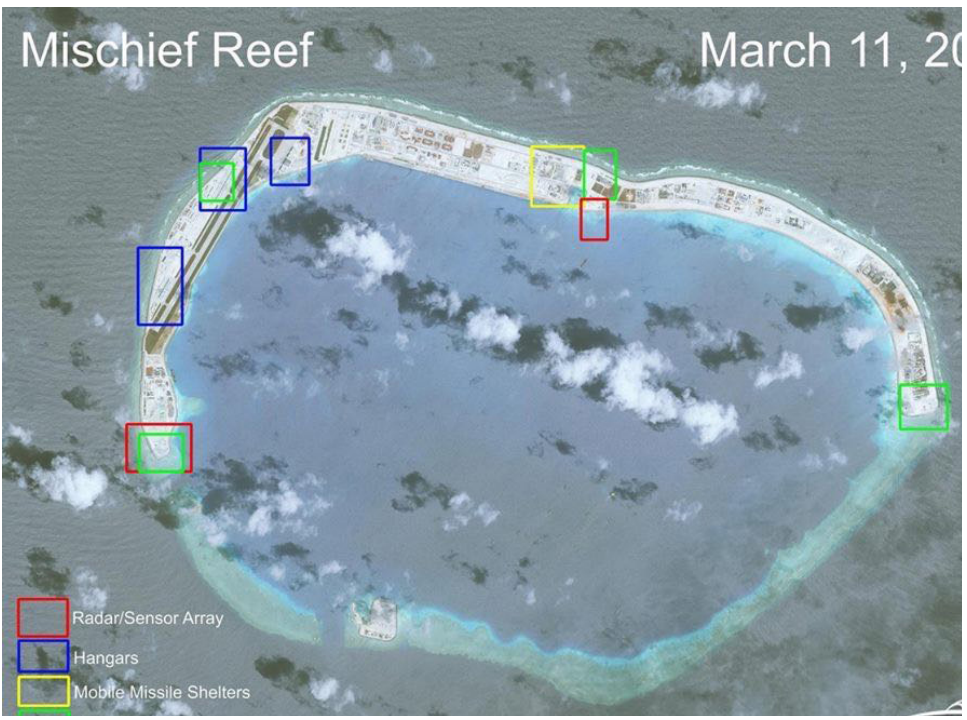

Picture 2. Military infrastructure and installations at Mischief Reef in the archipelago of Spratly

Source: China's Big Three Near Completion, Asia Maritime Transparency Initiative, Center for Strategic \& International Studies, https://amti.csis.org/chinas-big-three-near-completion, 29.06.2017, [access: 02.06.2018].

\section{Fiery Cross Reef March 9, 2017}

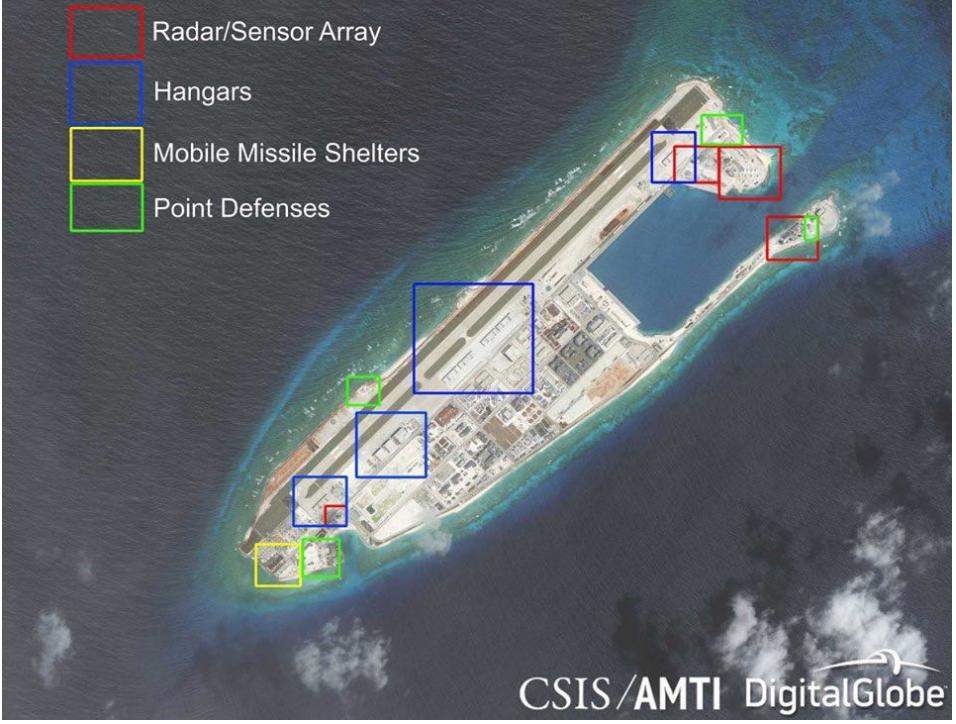

Picture 3. Military infrastructure and installations at Fiery Cross Reef in the Archipelago of Spratly

Source: China's Big Three Near Completion, Asia Maritime Transparency Initiative, Center for Strategic \& International Studies, https://amti.csis.org/chinas-big-three-nearcompletion, 29.06.2017, [access: 02.06.2018]. 


\section{Actors' Claims and Attempts to Find Possible Compromises}

The dispute and the claims of individual actors are motivated by many different reasons. Some countries in the region refer to a historical, legal or material foundation to their claims. They point to the first discovery of the islands in this region (China) or to the first arrival of citizens, in particular fishermen and sailors (China, Vietnam, Taiwan). Contemporary international law effectively negates historical claims, for example the presence of the Xia, Han and Tang dynasties (China), or the Ngyuen dynasty and the "inheritance" of French claims (Vietnam), privileging geographical proximity and usurpation as the bases of sovereignty over a given area without the need for permanent settlers. Such a position was stipulated in the judgment of the Permanent Court of Arbitration in the Hague in July 2016. The Tribunal, on the basis of the petition filed by the Philippines in 2013, refused China's claims under the Nine-Dash Line and condemned the degradation of the natural environment as a result of the construction of artificial islands. In addition, it recognised the island of Taiping, as well as other landforms of the archipelago of Spratly, as rocks that are not subject to the Convention on the Law of the Sea. This was rejected by both China and Taiwan, although supported by the EU and Japan.

At present, some South China Sea countries refer to the provisions of the United Nations Convention on the Law of the Sea (UNCLOS), which was signed on December 10, 1982 in Montego Bay in Jamaica. It entered into force in 1994. In total, it has been ratified by 168 countries, including the Philippines, Malaysia and Vietnam. These are supported by the US which, however, have not ratified it. The convention refers to the continental shelf, the delineation of territorial waters, the exclusive economic zone, i.e. 200 nautical miles (370 $\mathrm{km}$ ) from the baseline, and the delimitation of sea areas.

In 2018, a slight improvement in the relations between China and the Philippines, Malaysia and Vietnam was observed. This is evident by joint projects in the disputed area, and the withdrawal from planned investments and strategic projects for oil and gas extraction in territorial waters located in the South China Sea basin (Vietnam in 2017). In addition, after the electoral change of political authorities, the Philippines have criticized the decision to challenge Chinese territorial claims in the Permanent Court of Arbitration in the Hague by the previous Philippines administration. The statement following the $30^{\text {th }}$ ASEAN Manila Summit held in April 2017 also provided proof of change in policy direction. It did not include any reference to the trial on July 12, 2016.

Apart from pronounced claims and geopolitical designations in the South China Sea, it is important to address the specificity of political systems, national strategies, sovereignty and identities (Day, 2002; Acharya, 2001). In analyzing this context it should be underlined that these states are not homogeneous in terms of political regimes (Church, 2012). In this region there are presidential republics (the Philippines, Indonesia and Myanmar), federal constitutional monarchies (Malaysia and Cambodia), an authoritarian republic (Singapore), a military dictatorship (Thailand), an absolute monarchy - sultanate (Brunei), socialist 
republics (Vietnam as a communist dictatorship and Laos) and an authoritarian socialist republic (China). This complex political framework does not facilitate the development of existing relations. This is extremely important, taking into consideration the fact that these political differences are crucial in terms of internal national interests to maintain power and regimes, and the relatively newly proclaimed states after the end of WWII. Therefore, the matter of sovereignty is a very vulnerable question in this region (Day, 2002). The following dates show the chronological order in which these states gained independence: Indonesia (1945), the Philippines (1946), Myanmar (1948), the People's Republic of China (1949), Thailand (1949), Cambodia (1954), Laos (1954), Vietnam (1954), Malaysia (1957), Singapore (1965) and Brunei (1984). In this group of countries, Thailand and China have the longest history of statehood, but after the Second World War they also underwent a significant political, social and economic transformation. In the context of the current political environment and climate in this region, Michael Vatikiotis claimed that'populism and identity politics damage Southeast Asian democracy' (Vatikiotis, 2019).

ASEAN, founded in 1967, first referred to the dispute in the South China basin in a statement in 1992 and approved a code of conduct (COC) in 1996 (CSIS Expert Working Group on the South China Sea, 2018). In 2002, China and ASEAN agreed on a non-binding Declaration on the Conduct of Parties in the South China Sea (DOC). 'Since late 2016, consultations between China and ASEAN on a potential COC have gained new momentum. In August 2017 the parties adopted a bare-bones framework for the COC, and on August 2, 2018, Singapore's Foreign Minister Vivian Balakrishnan announced that the sides had reached agreement on a single draft negotiating text for the COC' (CSIS Expert Working Group on the South China Sea, 2018). The South-East Asian Nations Association summit held in Bangkok in June 2019, showed a positive climate among ASEAN members, but did not bring significant progress in the Code of Conduct (COC) activities in the South China Sea (Quang, 2019). China and ASEAN reached an agreement in November 2018 regarding the finalisation of the COC in three years, starting from 2019 (Quang, 2019). In the negotiation process, the most important problems include:

- the unspecified geographical range of the South China Sea;

- the lack of agreement on the dispute resolution mechanisms;

- the different approaches to conflict management (self-restraint, mutual trust and confidence building);

- the unspecified legal status of COC (Quang, 2019).

In spite of the involvement of the Association of Southeast Asian Nations under the ASEAN + 1 formula or ASEAN + China, in the alleviation of existing disputes and other multilateral and bilateral initiatives, SIPRI data reveal the ongoing arms race in the subregion, which is clearly illustrated on the map below. Nevertheless, ASEAN still constitutes a multilateral forum for addressing problems in this sub-region, like the United Nations, especially after Vietnam takes on its post as a non-permanent member of the Security Council in 2020-2021. 


\section{ChinaFears}

Southeast Asian states led an arms race in reaction to China's aggressive claims to islands in the South China Sea

\section{Defense spending increase from 2014}

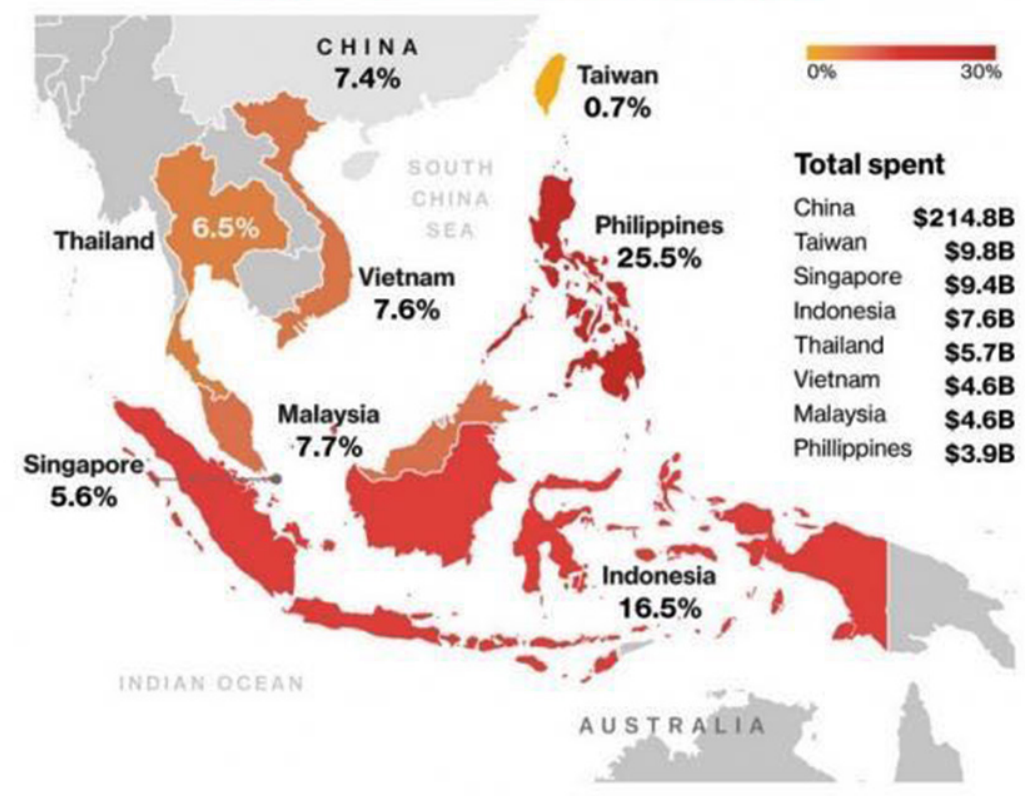

Map 3. The security dilemma in the South China Sea

Source: China Fears, SIPRI 2017, https://www.sipri.org/, [access: 22.04.17].

\section{Power Measurement in the South China Sea States}

The quantitative analysis of power has become increasingly popular as a new approach in contemporary geopolitics. According to Mirosław Sułek, 'powernomy is a science dealing with the power of political units (states, alliances, political and economic groups). Putting it more broadly - it is a science about the power (strength) of political units in international relations. It deals with the essence of power, its manifestations, the criteria of a superpower and the classification of political units according to the profile of their power. It is also the auxiliary science of political science and geopolitics. Powermetrics, in turn, deals with the modelling and measurement of power and it is a sub-discipline of powernomy' (Sułek, 2010, p. 61). Therefore, in relation to these notions, the approaches available in the literature are presented in the table below: 
Table 1. The selected methods for measuring power and the potential of states

\begin{tabular}{|c|c|}
\hline Clifford German - 1960 & $\begin{array}{l}\mathbf{G}=\text { National Power }=\mathbf{N}(\mathbf{L}+\mathbf{P}+\mathbf{I}+\mathbf{M}) \\
\mathrm{N}-\text { Nuclear Potential } \\
\mathrm{L}-\text { Territory } \\
\mathrm{P} \text { - Population } \\
\mathrm{I} \text { - Industrial Base } \\
\mathrm{M} \text { - Military Potential }\end{array}$ \\
\hline J. David Singer - 1963 & $\begin{array}{l}\text { CINC = (TPR + UPR + ISPR + ECR + MER + MPR): } 6 \\
\text { CINC = Composite Index of National Capability } \\
\text { TPR = Ratio of Total Population of the Country } \\
\text { UPR = Ratio of Urban Population of the Country } \\
\text { ISPR = Ratio of Domestic Production of Iron and Steel } \\
\text { ECR = Ratio of Energy Consumption } \\
\text { MER = Ratio of Expenditure on Reinforcement } \\
\text { MPR = Ratio of Military Personnel }\end{array}$ \\
\hline Singer and Small - 1975 & $\begin{array}{l}\text { Power } \frac{\text { tpop }+ \text { upop }+\mathrm{sp}+\mathrm{fc}+\mathrm{mb}+\mathrm{saf})}{6} \\
\text { tpop - total population } \\
\text { upop - urban population } \\
\mathrm{sp}-\text { steel production } \\
\mathrm{fc}-\text { fuel/coal production } \\
\mathrm{mb}-\text { military budget } \\
\text { saf - military personnel }\end{array}$ \\
\hline Ray Cline - 1977 & $\begin{array}{l}\mathbf{P p}=(\mathbf{C}+\mathbf{E}+\mathbf{M})(\mathbf{S}+\mathbf{W}) \\
\mathrm{C}-\text { Critical Mass (population and territory) } \\
\text { E - Economic Potential } \\
\text { M - Military Potential } \\
\text { S - Ratio of National Strategy } \\
\text { W - National Will }\end{array}$ \\
\hline Leszek Moczulski - 1999 & $\begin{array}{l}\mathbf{P}=\mathbf{m} \mathbf{x} \mathbf{i} \mathbf{x} \mathbf{d} \\
\text { P - Geopolitical Potential or General Potential } \\
\text { M - Material Potential } \\
\text { I - Intellectual Potential } \\
\text { D - Moral Potential (spiritual) }\end{array}$ \\
\hline $\begin{array}{l}\text { Comprehensive National } \\
\text { Power - CNP }\end{array}$ & $\begin{array}{l}\text { Strength }=\text { Critical Mass }+ \text { Economic Strength }+ \text { Military Strength: } 3 \\
\text { Where: Critical Mass }=((\text { Population of the Country: World Population }) \times 100)) \\
+((\text { Area: Area of the World }) \times 100))\end{array}$ \\
\hline
\end{tabular}

Source: own elaboration based on Chang, 2004; Treverton and Jones, 2005.

Referring to the level of power of the South China Sea states, and for the purposes of this article, I propose my own formula for the index of the Basic Geopolitical Potential of the State (BGPS), which is presented in the form of the following equation:

Module I Module II Module III

$\mathbf{B G P S}=(\mathrm{E}-\mathrm{N}) \times \frac{\mathrm{W}}{\mathrm{P}} \times \frac{\mathrm{N}}{\mathrm{F}}$ 
where:

BGPS $^{2}$ - Basic Geopolitical Potential of the State

P - Total Population of the State

E - Economic Strength Expressed in GDP (Purchasing Power Parity) of a Given Country

F - Military Force Expressed in Number of Soldiers

$\mathrm{N}$ - Military Expenditure

W - Workforce

The adopted index differs from currently existing more measurable indices and is based on available, objective statistical data. In addition, it focuses more on changing geopolitical factors, which depend directly on human will and social activities, and is much like modern geopolitics, including in its critical approach. It uses factors such as population (in various configurations), the economy (GDP is used in the majority of power indices) and military potential. Existing indicators often focus on permanent (or durable within a longer period) geopolitical factors, such as territory and culture, hard-to-measure (intellectual potential, spiritual potential, national will) or archaic data (nuclear potential or even iron and steel) due to the increasing role of new technologies. For the most part, the adopted indicators do not respond to the changing geopolitical conditions and potential of states.

What is more, the proposed power index focuses on the currently most important drivers of national power, namely population and the economy. Experts in the RAND Corporation have enumerated further drivers, such as domestic, sociopolitical, international, political, agricultural, energy, technological, environmental and qualitative (Treverton and Jones, 2005). As was underlined above, these modern factors have a non-permanent, non-durable nature and context. Therefore, this power index forms part of current research trends in contemporary geopolitics.

Elements of the introduced index structure have a more social and human-dependent character. This can be an effective hint for policy makers in regard to what directions change should take, in order to increase their key national total potential. It does not refer to geopolitically fixed categories such as territory, which might still generate changes through increasing territorial expansion (classical geopolitics). Such an assumption is close to contemporary geopolitics, the foundations of which are based on the criticism and rejection of the basic premise of classical geopolitics, which is dominated by geographical determinism. Nowadays, due to the ongoing processes of globalization and deterritorialization, territorial potential no longer plays such an important role, as a result of existing strong economic

2 This formula covers the most important available data in the scope of determining key constitutive and structural elements of the Basic Total Potential of the State or the basic general potential (according to Leszek Moczulski), including GDP (purchasing power parity), population and the army. 
interdependencies and transfers in the global economy, and the potential of raw materials, and intellectual, human or technological capital.

The relationship between the index proposed in this work and the geopolitical codes of the various countries of the South China Sea indicated below, is the result of the given strategies adopted by political decision makers involved in the conflict. Changes in the adopted index may cause a re-evaluation of the relational system: potential ally - potential enemy. In addition, geopolitical codes may be formulated based on the integrated and correlated data of the index.

The above results show the existing differences in the development of the South China Sea states. In contrast, the use of the proposed index illustrates China's clear dominance and the significant potential of Singapore, Indonesia and Taiwan, which is affected by the size of GDP expressed as Purchasing Power Parity. The weakest countries with the relatively smallest power (total potential) include Brunei, Cambodia and Vietnam. Upon examining the three modules in the proposed formula, however, the differences are not so clear. The first calculation module (Module 1) includes the mathematical approach to GDP (purchasing power parity) minus military expenditure. In this context, China remains the leader, followed by Indonesia, Thailand and Taiwan. Module 2, taking into account the workforce and the total population, slightly modifies the hierarchy of dominance in the region into: Singapore, Vietnam, China, Thailand and Taiwan.

Module 3, using the list of military expenditures in relation to the total number of active soldiers, highlights additional dependencies in the potential of individual actors. As a result, further changes are introduced in the arrangement of the countries of the South China Sea, which are presented as follows: Singapore, China, Taiwan, Cambodia, Malaysia. It is worth emphasizing that Brunei's position is shifting in the hierarchy, which means that the country is no longer the weakest of all in the area, as is the case for the second (population and workforce) and the third module (number of soldiers and army). It should be remembered, however, that these are only partial calculations influencing the final results, i.e. obtaining data on the basic geopolitical potential of the South China Sea states. These differences result from individual sizes, but they show the level of internal and external investments of individual countries in the region in strategic sectors of the state structure (economy, population and army).

\section{Geopolitical Codes of the South China Sea States}

The concept of geopolitical codes was first introduced by John Lewis Gaddis in 1982 in a publication entitled Strategies of containment: a critical appraisal of the American national security policy. It was further developed in the following works:

- Colin Flint - Introduction to geopolitics (2006),

- Peter James Taylor and Colin Flint - Political geography: world-economy, nationstate, and locality (2007), 

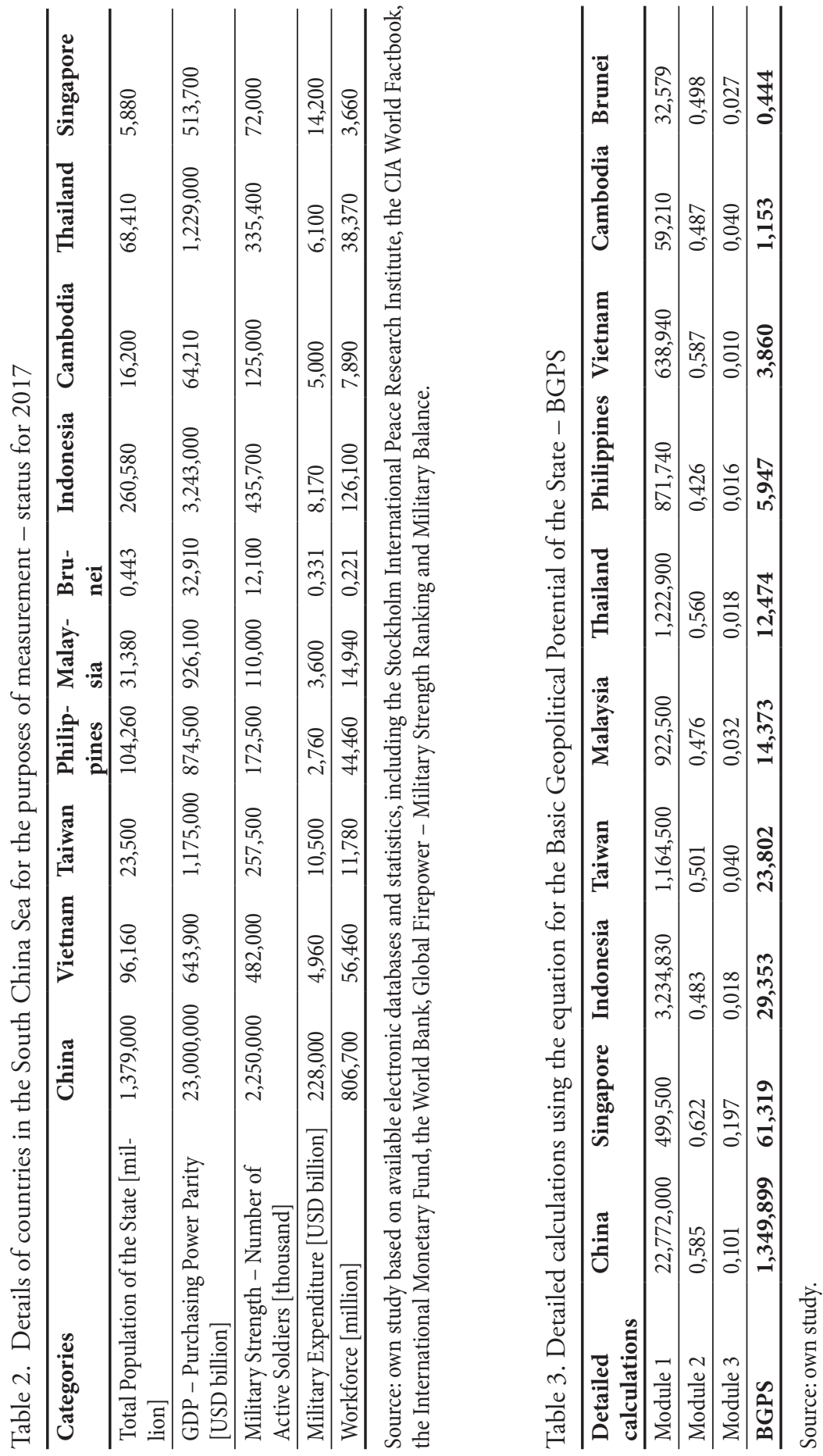
- Colin Flint, M. Adduci, M. Chen and S.-h. Chi - Mapping the dynamism of the United States'geopolitical code: the geography of the State of the Union speeches (2009).

What are, then, the geopolitical codes that determine the orientation of each state on the international arena? According to Peter James Taylor and Colin Flint, geopolitical codes are 'a set of strategic assumptions that the government formulates with respect to other countries as part of the foreign policy being created. [...] Such operational codes include the assessment of places outside the state borders in terms of their strategic importance and potential threats. Geopolitical codes are not just state-centric; they are also connected with a specific look of a given country on the world. By definition, they are therefore highly biased images of the world' (Taylor, Flint, 2007, p. 91).

In Poland, Julian Skrzyp, Jakub Potulski and Leszek Sykulski also referred to the concept of geopolitical codes. Nevertheless, as indicated above, none of the authors have used geopolitical codes to analyse the problem and geopolitical conditions of the South China Sea region.

The state of mutual and current relations between actors in this area is not only influenced by the community of needs, but by numerous interdependencies, economic, commercial or even military and political, which primarily dominate global and regional geopolitics. Undoubtedly, in this context, national, regional and global actors influence the shape of the status quo in the regional security sub-complex of the South China Sea. This is a highly integrated security area, determined by the diversity of threats, their multi-sectorality, the social structure of patterns of friendship and enmity, and a significant degree of polarization.

I have presented below the geopolitical codes of countries in the South China Sea. The analysis shows a high level of complexity in the relations between states in this area. For example, the occurrence of the same state in two positions, i.e. on the side of potential allies and potential enemies, results primarily from historical, political and commercial circumstances (China and Malaysia, China and the Philippines, and the USA and the Philippines). In addition, due to the fact that between the indicated countries of the sub-region there have been no modern armed conflicts on a large scale, apart from the period of the Cold War, commercial and economic factors seem to have a huge impact on the state of mutual relations. The details are defined in Table 4.

Table 4. Selected aspects of geopolitical codes of countries in the South China Sea

Source: own elaboration based on public Internet sources, own observations and analyses, The World Factbook - CIA and Taylor, Flint, 2007.

Geopolitical codes allow to determine the current place and status internationally of the states of the South China Sea sub-region. These codes also show that there are strong dependencies between the countries in this area. They, however, may differ from country to country due to changes in the international and their domestic environments. 


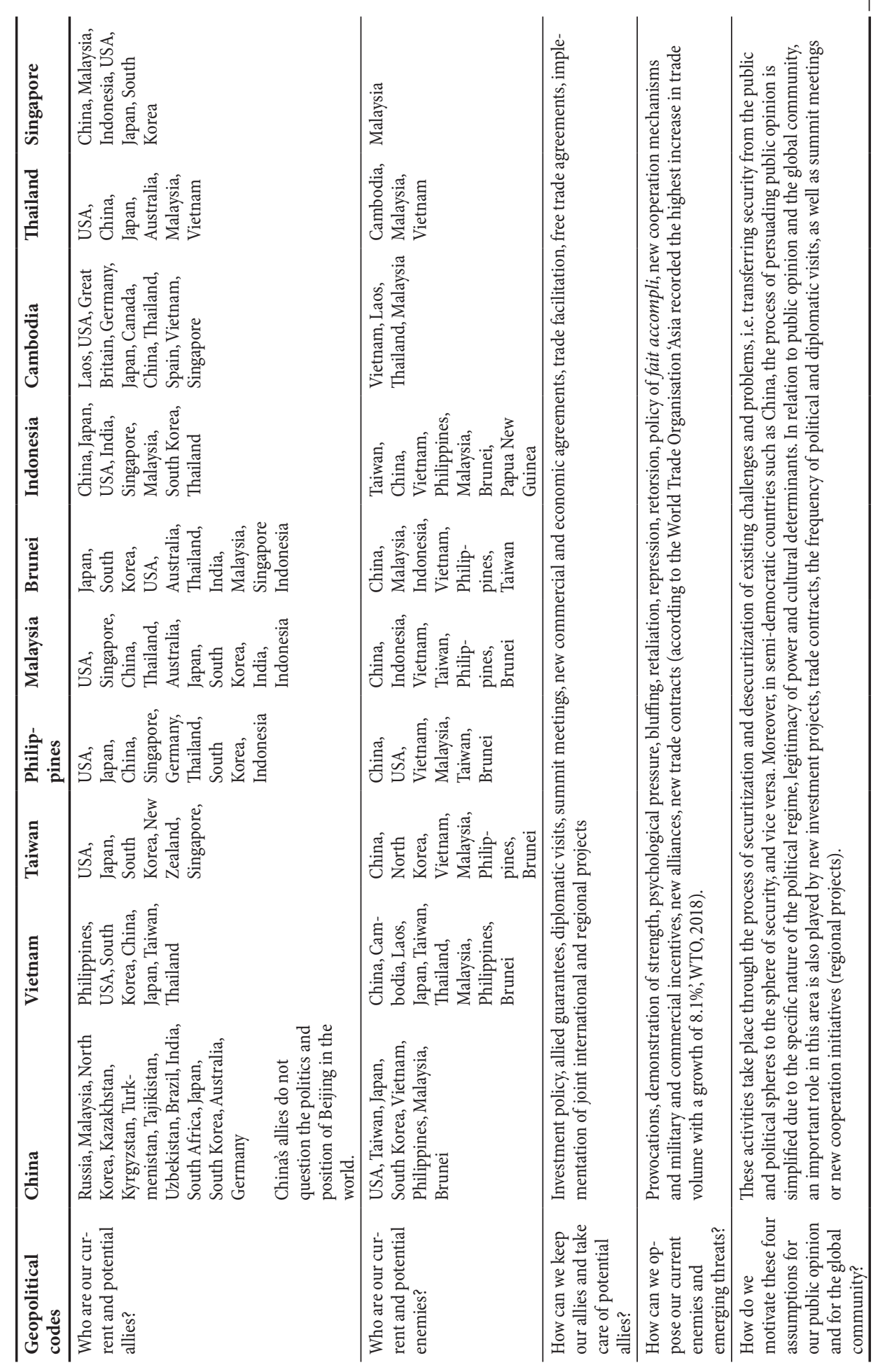


The above analysis revealed a basic epistemological difficulty in the unambiguous classification of a given country as an ally or an enemy. For example, in the case of countries located in the South China Sea, China holds grudges against the entire reservoir, which undermines the interests of other actors, while it also dominates foreign trade (both exports and imports) with almost all countries in the area: Vietnam (exports: 16\%, imports: 27\%), Taiwan (exports: 28\%), Malaysia (imports: 19\%), the Philippines (imports: 18\%), Indonesia (exports and imports: both 22\%), Singapore (exports: 13\%, imports: 14\%), Thailand (imports: 21\%), Cambodia (imports: 35\%), Brunei (imports: 25\%) (The World Factbook, 2018). This demonstrates the high economic and trade interdependence between China and other countries of the South China Sea, which to some extent is a catalyst for potential armed conflicts in the region.

In addition, the above data show that the economic and trade level, and strong macroeconomic interdependencies are the most important motives for cooperation among South China Sea countries. Despite existing differences and the geopolitical importance of the area (large resources, communication routes, etc.), it is the external economic and trade policies that are most effective in influencing the state of mutual relations and blurring the borders between potential allies and enemies. To that end, an action was taken to reduce the role of ASEAN in solving a dispute, as well as attracting new Chinese investments (Brunei, the Philippines, Malaysia, Vietnam and Taiwan). In such cases, historical, legal or political considerations do not adversely affect economic and commercial projects.

In addition, this region is interconnected through global foreign trade. According to WTO, China, Singapore, Taiwan, Thailand, Malaysia, Vietnam, Indonesia and the Philippines were 'leading exporters and importers in world merchandise trade among developing economies in 2016-2017. Singapore was the leading exporter of charges for the use of IP, with its exports totalling US $\$ 8$ billion in 2017. China was the biggest merchandise exporter in 2017, accounting for $13 \%$ of the world total' (WTO, 2018).

Currently, only the military factor, namely the military activity of individual states, the significant militarization of the South China Sea basin and the Sino-US rivalry, is a clear challenge to peace and security in the region. It lowers the level of mutual trust and intensifies existing tensions. In the case of China, such foreign policy tools, i.e. a combination of military, economic and trade instruments, form one coherent strategy for an effective geo-economic impact in this part of the world. Besides, this vision and the combination of soft power, hard power and smart power bring much greater benefits to China than the classic, confrontational concept of political and military pressure, and military activity alone adopted by the American administration (change of policy in regard to the Philippines and Malaysia, discontinuation of attempts to extract oil and gas through the territorial sea of Vietnam, and finally the increase of Brunei's dependence on China). Such a situation causes an increase in the share of Chinese investments in the GDP of individual South China Sea states, at the cost of a drop in American economic participation. Such trends are visible not only in the case of the Philippines, Indonesia, Vietnam and Brunei but, above all, in the 
richest countries in the region, such as Taiwan (the largest US ally following WWII, alongside Japan and South Korea) and Singapore.

Nevertheless, the analysis of geopolitical codes clearly shows that the most important actors from a global perspective on the current geopolitical situation in the South China Sea are China and the USA. This dominance will undoubtedly have an impact on potential increases or decreases in the level of hostility between countries in this part of Southeast Asia.

\section{Conclusions from the Analysis of Interstate Relations, and Perspectives for Resolving the Dispute in the South China Sea Basin}

This article shows the influence of the South China Sea on Asia's security and stability, as well as its geopolitical influence on international relations, and in particular on international trade. A factor heightening the tension in the South China Sea is the fact that Chinese demands cover between $80 \%$ and $90 \%$ of the entire sub-region, and all international decisions on this issue are challenged by China. In May 2017, China even threatened the Philippines, after the declaration of intent by President Rodrigo Duterte to look for oil in its part of the disputed area. China is also opposed to any interference in the region and strongly condemned the May 2017 statement of the G7 (USA, France, Canada, Germany, UK, Italy and Japan), which expressed concern about the situation in the South China Sea and the East China Sea, calling for the demilitarization of the disputed territories.

The South China Sea is becoming an arena for the rivalries of important actors of international relations to play out, such as China, USA, Japan and Australia. Russia has also recently actively participated in this strategic game in the South China Sea (Rosneft investments in the raw materials sector in the territorial waters of Vietnam). France and the United Kingdom have also become involved more intensively (announcements of sending war ships in 2020 to ensure the freedom of navigation in this area) (Xuequan,2017). During the presidency of Barack Obama, the US pursued a strategy of balancing the interests of the US and China with simultaneous focus on negotiations and multilateral forms of resolving the dispute, with the participation of China and US allies. The US has called for respect for international law and the UNCLOS provisions (assurances of Barack Obama and Hillary Clinton), although they have not themselves ratified the Convention on the Law of the Sea. After Donald Trump took over the office, this policy has changed from soft and conciliatory to more confrontational.

In spite of the withdrawal from the free trade agreement (Trans-Pacific Partnership -TPP), Americans remain militarily active in this area. This is evidenced by the patrol missions of American ships and missile destroyers, the sanctions and preventive diplomacy towards North Korea, and military manoeuvres with allies, including South Korea, Japan and Taiwan. An example of such activity are the events of March 2018. At that time, the USS Mustin rocket destroyer approached Mischief reef, where the Chinese have built an 
artificial island along with military infrastructure. The US administration proclaimed that the ship was carrying out a mission ensuring the freedom of navigation in accordance with international law, while Chinese authorities stressed that its actions posed a threat to China's security and sovereignty. The United Kingdom and Australia also joined this type of action on the side of the US. Apart from a few areas of cooperation in this region of Asia (Chinese support for negotiations with North Korea) or the American-Chinese search for an American seaman who fell overboard in the Huangyan Island (Scarborough Shoal), the interests of the US and China still remain divergent. Matters are exacerbated by the fact that the South China Sea is also a strategic part of the Chinese, political and geo-economic initiative of the Belt and Road Initiative, launched in 2013 in Astana in Kazakhstan.

The above analyses (power measurement of the South China Sea states) show the clear dominance of China, and the strong economic and trade dependence of other countries in the area on the People's Republic of China. In this context, one possible scenario is the gradual economic dependence of the South China Sea countries on China and the use of soft power by Beijing. This financial strategy of attracting potential partners begins to bring tangible benefits. An example is the alleged suspension of claims by Brunei or joint projects in the mining of raw materials between China and the Philippines in the South China Sea. In addition, since 2016, Brunei, together with Laos and Cambodia, have started to advocate that disputes in the South China Sea should be resolved through dialogue and consultation between the parties directly concerned, rather than in multilateral fora and in particular under ASEAN (Hart, 2018). Undoubtedly, such a scenario is also in line with the decision of Vietnam, which for the second time in the last dozen months, this time in the Ca Rong Do field (Red Emperor) in the Nam Con Son basin, suspended a project of oil and gas extraction by the Spanish company Repsol, even though oil reserves are estimated there to be at a level of 45 million barrels, and natural gas at a level of 172 billion cubic feet.

\section{References}

Acharya, A. (2001). Constructing a Security Community in Southeast Asia. ASEAN and the problem of regional order. London, New York: Routledge.

Chang Ch.-L. (2004). A Mesure of National Power. http://www.analytickecentrum.cz/upload/soubor/ original/measure-power.pdf, [access: 26.07.2019].

Asia Maritime Transparency Initiative, Center for Strategic \& International Studies. (2017). China's Big Three near completion. https://amti.csis.org/chinas-big-three-near-completion, 29.06.2017, [access: 02.06.2018].

Asia Maritime Transparency Initiative, Center for Strategic \& International Studies. (2017). China's Continuing Reclamation in the Paracels. https://amti.csis.org/paracels-beijings-other-buildup/, 09.08.2017, [access: 03.06.2018].

Białoskórski, R., Kiczma, Ł. Sułek, M. (2018). Potęga państw 2018. Międzynarodowy układ sił w procesie zmian. Raport potegometryczny, Warszawa: Oficyna Wydawnicza ASPRA-JR. 
Białoskórski, R., Kobryński, R., Sułek, M. (2017). Potęga państw 2017. Międzynarodowy układ sit $w$ procesie zmian. Raport potegometryczny, Warszawa: Oficyna Wydawnicza ASPRA-JR.

SIPRI. (2017). China Fears. https://www.sipri.org/, [access: 22.04.17].

Church, P. (2012). A Short History of South-East Asia. John Wiley \& Sons.

CSIS Expert Working Group on the South China Sea, A Blueprint for a South China Sea Code of Conduct, South China Sea Expert Working Group, Asia Maritime Transparency Initiative. (2018). https://amti.csis.org/blueprint-for-south-china-sea-code-of-conduct/, [access: 24.07.2019].

Daiss, T. (2018). How Oil Drives The South China Sea Conflict. Oilprice.com. https://oilprice.com/ Energy/Energy-General/How-Oil-Drives-The-South-China-Sea-Conflict.html, 14.03.2018, [access: 02.06.2018].

Day, T. (2002). Fluid Iron. State Formation in Southeast Asia, University of Hawai'i Press, Honolulu.

Friedman, G., Snyder, X., Ligon, Ch. (2017). Chinese Military Installations in the South China Sea.http:// www.mauldineconomics.com/this-week-in-geopolitics/chinese-military-installations-in-the-southchina-sea, 27.03.2017, [access: 02.06.2018].

Stratfor. (2017). Great Power Politics in the South China Sea. https://worldview.stratfor.com/article/ great-power-politics-south-china-sea, 26.10.2015, [access: 23.05.18].

Hart, M. (2018). Brunei Abandons South China Sea Claim for Chinese Finance. Geopolitical Monitor. 04.04.2018, https://www.geopoliticalmonitor.com/brunei-abandons-south-china-sea-claim-forchinese-finance, [access: 03.06.2018].

Hastedt, G., Lybecker, D.L., Shannon, V.P. (2015). Cases in International Relations. Pathways to Conflict and Cooperation, Power Management in the South China Sea. Los Angeles: SAGE.

Kelly, T., Kubo, N. (2017). Japan plans to send largest warship to South China Sea. http://www.reuters. com/article/us-japan-navy-southchinasea-exclusive-idUSKBN16K0UP?utm_source=facebook\&utm_ medium=Social, 13.03.2017, [access: 03.06.2018].

Center of International Relations. (2016). Morze Południowochińskie: serce potencjalnego konfliktu w Azji. Report, Warsaw, May.

O’Tuathail, G., Dalby, S. (1998). Introduction: rethinking geopolitics: towards a critical geopolitics. In Rethinking geopolitics. London.

Potulski, J. (2013). Morze Południowochińskie jako obszar konfliktów międzynarodowych. Gdańskie Studia Azji Wschodniej, No. 3.

Potulski, J. (2010). Wprowadzenie do Geopolityki. Gdańsk: Wydawnictwo Uniwersytetu Gdańskiego.

Quang, N.M. (2019). Saving the China-ASEAN South China Sea Code of Conduct. The Diplomat. https://thediplomat.com/2019/06/saving-the-china-asean-south-china-sea-code-of-conduct/ [access: 25.07.2019].

Geopolitical Monitor. (2018). South China Sea Dispute: China. https://www.geopoliticalmonitor.com/ south-china-sea-dispute-china/, 08.05.2018, [access: 23.05.18].

Sułek, M. (2010). O potęgonomii i potegometrii. In Geopolityka. elementy teorii, wybrane metody i badania,. Z. Lach, J. Wendt (Eds.), Częstochowa: Instytut Geopolityki.

Sykulski, L. (2014). Geopolityka. Częstochowa: Wydawnictwo Naukowe Grategia.

Tarnogórski, R. (2016). Przyczyny i konsekwencje arbitrażu w sprawie Morza Południowochińskiego. No. 45 (1395), 18.07.2016, the Polish Institute of International Affairs, Warsaw.

Taylor, P.J., Flint, C. (2007). Political Geography: World-economy, Nation-state, and Locality. Harlow: Pearson Education.

CIA. The World Factbook. https://www.cia.gov/library/publications/the-world-factbook, [access: 02.06.2018]. 
Treverton, G.F., Jones, S.G. (2005). Measuring National Power. RAND Corporation. https://www.rand. org/content/dam/rand/pubs/conf_proceedings/2005/RAND_CF215.pdf, [access: 26.07.2019].

WTO. (2018). World Trade Statistical Review 2018. https://www.wto.org/english/res_e/statis_e/ wts2018_e/wts2018_e.pdf, [access: 30.01.2019].

Vatikiotis, M. (2019). Populism and identity politics damage Southeast Asian democracy. Nikkei Asian Review.

Xuequan, M. (2017). Non-regional countries' interference in South China Sea issue "worth maintaining vigilance". Xinhua. http://www.xinhuanet.com/english/2017-07/28/c_136481286.htm, 28.07.2017, [access: 03.06.2018].

\section{Author}

\section{Marek Musioł}

PhD, marek.musiol@uwr.edu.pl - University of Wrocław, Institute of International Studies, Department of Security Studies 